sion following Pullman and transformed into the Progressive Era movement of the urban middle class.

Finally, the OAH bestowed its Merle Curti Award on David Roediger's The Wages of Whiteness: Race and the Making of the American Working Class (Verso).

\title{
Reworking American Labor History: Race, Gender, and Class
}

\section{David A. Zonderman}

University of Wisconsin-Madison

On April 9-11, 1992, the State Historical Society of Wisconsin and the Department of History at the University of Wisconsin-Madison cosponsored the conference "Reworking American Labor History: Race, Gender, and Class." The conference brought together over one hundred scholars from across the United States to hear fifteen panels containing forty papers on all aspects of American labor history. The meeting opened up many new avenues of historical inquiry into the lives and labor of previously unexplored working people and the roots of cultural diversity in the American workplace. It challenged all labor historians to consider how the basic social constructs of race and gender, which were entwined in nearly all the papers presented, can broaden the terrain of the discipline in its totality.

The meeting was highlighted by two plenary papers, commissioned by the conference organizers, on the conference's theme as a whole. Robin Kelley's presentation, " 'We Are Not What We Seem': Rethinking Black Working-Class Opposition in the Twentieth-Century South," called on the audience to investigate and analyze the richly textured world of African-American families, neighborhoods, churches, fraternal organizations, and other sites of black self-expression and resistance to racist oppression. Kelley wove together the sources and techniques of labor history, cultural history, and African-American history into a densely packed essay which showed both the wealth of material available for immediate research and the long-range potential which such studies might hold for the future direction of American labor history.

Ava Baron's “On Looking at Men: Masculinity and Working-Class History" discussed the significance of exploring masculinity as an analytical framework for writing labor history, and the contributions of women's history and feminist theory to the formulation of these concepts of masculinity and gender itself. Baron examined how the construction of gender, while frequently linked with women's history research, can be applied very fruitfully to the study of workingmen as gendered subjects and as subject to the ideology of masculinity. Baron further argued that seeing male and female workers as shaped by gendered definitions of themselves, and their interactions with each other, opens up even more fundamental questions about the historical development of the American working class. 
Many of the conference panels picked up on Kelley and Baron's calls for bringing race and gender into the center of labor history research and theory. Sessions on "Race, Religion, and Culture in Antebellum America," "The Working Class at Mid-Century: New Thoughts on Politics and Race," and "Organized Labor and Civil Rights" traced more than one hundred years of the often tense relations between black and white workers within, and beyond, the organized labor movement. Two panels focused on the concept of gender in workingmen's lives - "Varieties of Working-Class Masculinity" and "Working-Class Masculinity in the Nineteenth Century." Two other panels demonstrated continuing vitality in the field of women's labor history - "Images and Reality in Working Women's Experience" and "Domestic Labor and Domestic Lives." There were other sessions which set workingmen and workingwomen in a comparative framework. "Reconstructing the Home in the Rhetoric of WorkingClass Protest" examined how men and women conceptualized the language of domesticity in the nineteenth century. "Gender and Welfare Capitalism" discussed how male and female workers responded to various corporate welfare schemes in the twentieth century.

Several sessions strived to encompass a wide range of analytical perspectives in their presentations; race, gender, class, and ethnicity all figured prominently in these panels. "Family, Labor, and the Immigrant Working Class" examined the interaction of women's labor, family structure, and class formation in immigrant communities. "The Culture of Communism" considered how family life, fraternalism, and the struggle for racial solidarity, all shaped communist workers and unions. "The Challenge of Race and Gender in Organizing Labor" and "Race, Ethnicity, and Gender in Industrial Unions" both explored the struggles within the twentieth-century labor movement to break down its own internal prejudices and organize an increasingly diverse working population.

In addition to the sessions, the first full day of the conference concluded with a keynote address by Jacquelyn Dowd-Hall. "Sex, Lies, and Subjectivity: The Personal and the Political in Working-Class Women's Lives" was a moving, and even intimate, portrait of Delight Smith, a labor organizer in early twentieth-century Atlanta. Dowd-Hall carefully analyzed Smith's public activism and personal life to show how one "ordinary" woman's world can yield extraordinary insights into the complex interactions of class and gender, politics and passion, and love and wage labor among workingmen and workingwomen.

Conference participants were nearly unanimous in their praise for the ways in which the papers and panels revealed both new empirical research and raised new theoretical challenges for the field of American labor history as a whole. Labor historians, if they are serious about bringing the concepts of race, gender, and class into the core of their intellectual projects, will be forced to reconsider more of the traditional subjects and methodologies in the discipline. These ideas must be seen as something more important than a new intellectual mantra, or a new orthodoxy, to which scholars must make passing gestures of obeisance. These concepts must be used rigorously to open new questions about how and what we study in American labor history. Studies of organized labor, politics, and union leadership certainly need not be scrapped: many of the conference papers attest to their continuing importance. But these more familiar modes of inquiry are given new analytical life when they are examined within themselves and placed in a broader context, through the conceptual lenses of race, gender, and class. 
The modest size of the conference, as well as the ambitious theme, was the subject of some discussion. Many participants saw the relatively small number of attendees as a source of both strength and weakness. Virtually everyone at the conference had a chance to meet one another and to engage in meaningful conversations within and outside of the sessions. However, attendance at some of the panels was somewhat low, and the audiences sometimes remained relatively unresponsive. Several participants also noted that such an important and intellectually stimulating meeting should have been publicized to a wider audience so that more people in and around the field of labor history could have heard the important challenges to the received wisdom, and of the opportunities for further cutting-edge research. $I L W C H$ readers should know that another labor-history meeting is being planned to convene in Madison in the spring of 1994. 